\title{
EVALUATION OF OPEN LEADERSHIP AND INNOVATION ORIENTATION ON EMPLOYEES AND CULTURE OF THE ORGANIZATION
}

\author{
Fatma SONMEZ CAKIR ${ }^{(1)}{ }^{1}$, Zafer ADIGUZEL ${ }^{(1)}{ }^{2}$ \\ ${ }^{1}$ Bartin University, Bartin, Turkey \\ ${ }^{2}$ Istanbul Medipol University, Istanbul, 34810, Turkey \\ E-mails: ${ }^{1}$ ssonmez@bartin.edu.tr; ${ }^{2}$ zadiguzel@medipol.edu.tr (corresponding author)
}

Received 12 September 2019; accepted 21 October 2019

\begin{abstract}
In the production sector, where innovation and creativity activities are intensely realized, organizations need not only creativity activities but also process management in a successful organizational culture in order to be successful in the competitive environment in terms of both leadership and innovation activities. In terms of leadership, institutions need to be managed with a correct understanding. The aim of this study is to analyze the relationships between open leadership, innovation orientation, employee creativity, organizational culture and process management variables. In this study, the effects of open leadership role on innovation and employee creativity activities and process management were investigated. At the same time, innovation orientation mediated effect was demonstrated. In the scope of aim of the study, a survey was conducted with 418 engineers working in the production sector. IBM SPSS 25 program, LISREL program and SOBEL calculation tool were used in the analysis. The data obtained were evaluated. Confirmatory and explanatory factor analysis and reliability analysis were performed on questions used Likert scale. In this study, it is concluded that the mediation variable effect of innovation orientation variable is on both organizational culture and creativity and process management.
\end{abstract}

Keywords: open leadership, innovation orientation, employee creativity, organizational culture, process management, production, company.

JEL Classification: L230, O310, M530, M100.

\section{Introduction}

Today's society is experiencing an era of changes. Every kind of change brings with it its own new rules. The primary structures of these new rules are the public / private organizational structures. In this sense, change is triggering a new order and environment for organizations. Surviving in such a new environment requires more and more changes for organizations. According to Gary Hamel, 30 thousand of new products are released each year and $90 \%$ are not successful, but the rest can reach the success (Hamel 2006). According to the results of empirical studies on new products, the rate of failure in products is reported to be around $40 \%$, although rates in different sectors differ (Castellion 2012). In the following year, Castellion and Markham (2013) examined studies on new product failure rates and found that these rates were $80 \%$ or more over the years.
Experts estimate that businesses in the manufacturing sector spend more than $\$ 20$ million on a new brand and 80 to 95 percent of new brands fail (Perreault et al. 2013). In other words, only $10 \%-20 \%$ of new products in the production sector can stay on the market every year. This means that hundreds of billions of dollars of spent on products that fail worldwide went to waste. The main reason for this is due to the problems in leadership and the innovation. But in order to ensure change, organizations always need a successful leadership style. In this context, leadership for the organizational structure is actually the art of making a kind of interdependence between organizations and employees acting in the same direction. Because as a fundamental feature of today's modern organizations, it is accepted that no one has complete autonomy, that all employees are connected to each other with the technology, management

Copyright ( 2019 The Authors. Published by VGTU Press.

This is an Open Access article distributed under the terms of the Creative Commons Attribution License (http://creativecommons.org/licenses/by/4.0/), which permits unrestricted use, distribution, and reproduction in any medium, provided the original author and source are credited.. 
systems and hierarchy connection in the organization and they have created a culture of mutual dependence (Kotter 2011). Creativity has the personality structure, intellectual accumulation, the ability to perceive, transfer and intuition life, in which the content is dominated by individual freedom. In this context, creativity is the process in which one uses all of its features in a problem faced by the individual and tries to produce what is not, or, if so, different. When the literature is examined, it is understood that the most important part of the research in the field of creativity is based on the psychological characteristics of individuals such as motivation, their cognitive qualities and accordingly their intellectual and knowledge levels. In other words, the factors that reveal creativity have been investigated in relation to the psychological and cognitive qualities of individuals. However, it has been determined in the researches carried out in the future that it is effective in the emergence of creativity in social and environmental factors. In fact Sternberg and Lubart (1999), listed the scientific studies in the field of creativity in six main titles such as, mystical, pragmatic, psychodynamic, psychometric, cognitive, social and personality-based approach as based on the characteristics; however, they emphasized that a multi-element approach has been adopted in creativity researches, especially since the 90s (Sternberg and Lubart 1999). In particular, this knowledge accumulation shows that the creativity of employees is a valuable resource that increases organizational competence (eg efficiency of production innovation), financial performance (eg, relative sales, return on investment and profitability) and marketing performance (eg. market share) (Lopez-Cabrales et al. 2009, Shin et al. 2012). According to the literature, continuous improvement, creativity, process management and organizations must explore a common approach to discover and implement new ways of improving operations (Anand et al. 2009). In this respect, the importance of open leadership and innovation focus is essential for the sustainability of the activities of the organizations. Because sustaining innovation and having a leadership understanding that supports innovation are important elements of being successful in a competitive environment. In addition, a research model has been developed to determine whether both open leadership and innovation orientation practices can facilitate the development of creative effectiveness in organizational employees, affect organizational culture and are effective on process management.

\section{Theory}

\subsection{Open leadership}

One of the most important forces in organizations' ability to continue their activities in a competitive environment is undoubtedly the leaders (Johan and Handika 2018). Leaders always use their powers to improve the performance of the organizations they manage (Lohrke et al. 2004). Open leadership is one of the leadership styles examined whether organizations are successful in innovation, process and performance (Dewey 2019). Although the concept of open leadership is very new in the literature, it is a leadership style that stands out among other types of leadership due to the change in the interpersonal relationship process and the emphasis on the quality of this situation (Li 2010, Uslu et al. 2015). Especially due to the intense interest in social networking technologies (internet based) in the interpersonal close relationship process in the 21st century; sharing, commenting, organizing and controlling elements are more prominent than in previous periods (Li 2010). Open leaders have the characteristics of being able to think independently, be cooperative and optimistic. Open leadership is based on trust in the work they do with the employees in the relationship between them and the realization of the goals of the realization of the principles of behavior in the process (Reichstein and Michelis 2015). Characteristics expected to be in open leaders; is to accept the power of employees, to guide all kinds of processes and to accept the potential of the employees / service recipients to influence. In organizational culture, the importance of leadership style is seen in terms of reflecting the creativity activities of the employees to the process management (Adeel et al. 2018). Especially in innovation-oriented organizations, the creativity activities of the employees are positively reflected in the performance.

The most important characteristics of open leaders are the fact that they are contributing to creating new relationships and trust between employees and customers through social networks such as blogs, twitter, facebook and other new technology products (Karcioğlu and Kurt 2009). Thanks to this feature of leaders with open leadership characteristics, innovation orientation can positively reflect the organization's process and performance. Open leaders display curiosity about what one is doing / why something is important to that person. Open leaders provide all kinds of comments to the employees about the activities carried out, but people should be aware that they will be responsible for the consequences when they abuse the right to comment. Open leaders should be able to achieve a sense of trust within the organization and pursue an accountability philosophy by understanding the importance of supporting this with continuous sharing. It should maintain a leadership path with the virtue of forgiving failures as necessary by supporting all kinds of curiosity and modesty (Polat and Arabac1 2014). For this reason, the effects of open leadership on the organization and employees as well as the intervening variable effects of innovation orientation on the organization are examined. 


\subsection{Innovation orientation}

Innovation orientation is a philosophy that promotes openness to new ideas and reflects an organization's willingness to change through the adoption and application of new technologies, resources, skills and administrative systems (Han et al. 1998). Innovation orientation promotes risk taking and increases the likelihood of designing and developing entirely new and innovative products (Olson et al. 2005). Innovation orientation is a way of thinking and pioneering that makes the organization long-term and innovative (Siguaw et al. 2006). Innovation offers significant advantages to organizations such as maintaining or increasing market share, performing better than its competitors (Lisboa et al. 2011, Wendra et al. 2019). The imbalance in customers' preferences and expectations significantly limits an organization's ability to satisfy existing products by making small changes or even increasing innovations (Zhou et al. 2005). On the other hand, demand uncertainty requires the adoption of more radical innovations that will meet the needs of changing customers and strengthen the competitive position of the organization in the market. Organizations can develop a competitive advantage by exhibiting innovative behavior (Hurley and Hult 1998). Some researchers see innovation as the best way for an organization to gain a competitive edge and renew its competitive advantage (Olavarrieta and Friedmann 2008).

Innovative organizations can perform better than their competitors by effectively replacing existing products or offering new products to the market that benefit customers (Deshpandé et al. 1993, Szymańska et al. 2017). These organizations, in an intensely competitive environment of innovation, can deter organizations from investing in innovation, but at the same time, they can decide to imitate competitors' innovations to reduce costs (Olavarrieta and Friedmann 2008, Zhou et al. 2005). In a broad sense, the definition of innovation includes not only product or service innovations but also innovations in production and technologies and administrative processes that can contribute to significant cost reduction and operational efficiency (Gatignon and Xuereb 1997, Han et al. 1998). Siguaw et al. (2006) argue that the long-term success of an organization can be based on a innovation orientation at the general firm level, which produces innovations and less specific endeavors. There is a culture of innovation that encourages new ideas in organizations that operate in competitive markets (Hurley and Hult 1998). Innovation orientation has been providing innovative behavior to improve quality and significant benefits over many years. In addition to the values offered to customers, it is aimed at increasing the efficiency of value chain activities. Particularly in the research, the reason for analyzing the intervening variable effect of the innovation orientation variable as an interim variable is the intensive realization of innovation activities in the production sector, and therefore the effects of both organizational culture and creativity and process management. In the context, the following hypothesis was developed:

$\mathrm{H} 1$ : There is a positive relationship between open leadership and innovation orientation.

\subsection{Employee creativity}

The creativity of employees is a phenomenon at the individual level and defines the production of new and organizationally valuable ideas (Amabile 1995). The climate of the organization is defined as one of the most dominant predictors of employee creativity (Mumford et al. 2002). In a supportive organizational climate, it is an inseparable feature that can help employees pursue creativity and use their creative potential (Williams and Foti 2011). Supportive innovation of an organization can positively affect an employee's creative and innovative behavior (Jung et al. 2003). Černe et al. (2013) stated that promoting innovation plays an important mediating role in promoting creativity among individuals. Thus, individuals who value innovation and work with an approach that tolerates errors exhibit higher levels of creative behavior. Wang et al. (2013) stated that employees' creativity has improved significantly in organizations with high innovation climate. To get support from their organizations, employees can develop and adopt the behaviors expected by the innovation climate (Dragoni 2005). Therefore, it is rational to suggest that the climate of innovation of the organization has a positive relationship with the creativity of the employees. Creativity is expressed as the production of new and useful ideas in any subject (Amabile 1983); According to another definition, creativity is the discovery, combination and production of new ideas from existing ideas (Higgins and Morgan 2000). Barker defines creativity as the ability to create new ideas and an activity that brings innovation (Barker 2002). Levitt's creativity, according to most people, is very important and describes the original ideas as throwing (Levitt 2002). According to Toffler, in order for innovation to occur, firstly there must be a creative and applicable idea, the application of this idea and the application of the applied thought must be expanded (Toffler 1981). Boden recognizes creativity as creating new, illuminating, useful and useful ideas (Boden 1990). We can define creativity from the definitions of creativity in the literature as producing new, original, useful and helpful ideas and methods in any subject. In creativity, not only is the idea produced new, but it should also be original, useful and helpful. It is stated that the individual is the most important source of creativity (Redmond et al. 1993). Although creativity is thought to be an innate trait, inspiring and uncontrollable power, it is an idea production that can be acquired and processes. Rawlinson explains that in every human being, there is creativity, but in some individuals, external factors and creative abilities 
are forced to be covered by another set of skills (Rawlinson 1995). In the research, the effects of the organizations on the creativity activities are examined with the adoption of both the leadership styles and the leadership style of the organizations in the intense competition environment. In the context, the following hypothesis was developed:

$\mathrm{H} 2$ : There is a positive relationship between open leadership and employee creativity.

$\mathrm{H} 5$ : There is a positive relationship between innovation orientation and employee creativity.

H8: In the relationship between open leadership and employee creativity, the innovation orientation intervening variable has a positive effect.

\subsection{Organizational culture}

Organizational culture is described as the ultimate effect of individuals on conscious and subconscious thought and decision making, as well as the ultimate effect of improving and maintaining organizational performance (Lok and Crawford 2003). Camic (1986) argues that not only the employees but also their managers involved, on the one hand, consciousness or reflection, on the other hand, the cultural culture is adopted within the organization and the organizational culture. Essentially, organizational culture is the common awareness of colleagues with common assumptions, values, beliefs and norms (Schein 1985). Lai and Lee (2007) explain that organizational culture consists of an understanding of evolving shared interpretations and organizational events. Schein (2004) explains that organizational culture, beliefs, and values are shared by internal stakeholders, and that employees are formed by the adoption of facts such as language, story, ceremony. Organizational culture includes values, philosophy and missions, but also reflects employees' actions and perspectives (McDermott and O'Dell 2001). Organizational culture is considered to be a critical factor that strongly influences employees' knowledge sharing behavior in the organization (Lee et al. 2016). Organizational culture is seen as an effective "glue" that brings together the organizational members by providing the cultural characteristics of consistency and consistency. Within the concept of organizational culture, it may be possible for the employees to have a different understanding of authority in high standards, regular, cautious and systematic ways of working (Chen et al. 2012). Because if there is an authoritarian understanding of leadership in the sense of leadership, employees can perform a lower performance, and employees in such an organizational culture may be deprived of autonomy and independence. In contrast, the autonomy given to employees when organizational culture is governed by a nonauthoritarian leadership style is often seen as an important component of psychological well-being for employees, as noted by Ryff and Keyes (1995) and Ryff and Singer (2008).
Jung (1933), emphasizing the importance of organizational culture, emphasizes the importance of autonomy, that is, the importance of "individualization" in the adoption of the organizational culture of employees. Wallach (1983) and Yiing and Ahmad (2009) state that organizational culture must have a creative, challenging, result-oriented and risky working environment to adopt an innovative culture. Members of the organization involved in an innovative culture are more creative and free; therefore, they are more likely to be useful to the organization (Chen et al. 2012, Koberg and Chusmir 1987). Organizational culture also has the property of encouraging employees not only to carry out designated tasks, but also to continuously improve their potential (Ryff and Singer 2008). For this reason, it is aimed to examine and analyze the effects of open leadership style and innovation phenomenon on the culture of the organization. In the context, the following hypothesis was developed:

H4: There is a positive relationship between open leadership and organisational culture.

H6: There is a positive relationship between innovation orientation and organisational culture.

H9: Innovation orientation has a mediation variable effect on the relationship between open leadership and organisational culture.

\subsection{Process management}

One of the most important stages in the organizations in the production sector is that they can have continuous improvement competence. They have a dynamic structure in the competitive environment in organizations that are in continuous improvement. Organizations need to be able to manage this process very well in order to be successful in process improvement. Organizations primarily focus on processes and stages as a basis for current work on new product development and creativity (Kindström and Kowalkowski 2009). In the new product development and creativity stages, the organization should give importance to the feedback from customers (Carbonell et al. 2009, Lundkvist and Yakhlef 2004), and at the same time the most important factors in new product development and creativity are profitability, market share and cost management. Because of these factors, the organization can allocate resources to $\mathrm{R} \& \mathrm{D}$, that is, new product development process (Chen et al. 2009, Melton and Hartline 2010). Process management in manufacturing companies is very different from the process development in service companies. While organizations tend to rely on R \& D departments in process management, they also acknowledge that their success is related to employee skills in the $\mathrm{R} \& \mathrm{D}$ department (Nijssen et al. 2006). It is suggested that the skills of the employees are an important source for the organizations to achieve competitive advantage and to be 
competitive (Colbert 2004). This applies not only to managers and employees, but also to employees in the operational process in production departments. The role of employees is becoming more important as they have to deal with more complex tasks such as developing specialized products and improving product processes. By undertaking such complex tasks, employees are enabled to be more competent in improving process management performance with the changing needs of customers and developing new product processes (Johnson et al. 2000, Ordanini and Parasuraman 2010). In addition, this understanding provides employees with insights into the need to overcome challenging tasks, such as understanding customer needs, analyzing product problems, developing new product processes, and learning new skills while engaging employees in process management activities. When the literature on the performance of employees regarding the effective implementation of these challenging tasks is examined, process management shows that employees can be highly relevant in terms of being creative, seeking innovation and excellence in their tasks, and dynamically performing well (Baer and Oldham 2006). In the research, the effects of both leadership style and innovation orientation concept on process management are analyzed because of the product development activities of the production companies. In the context, the following hypothesis was developed:

H3: There is a positive relationship between open leadership and process management.

H7: There is a positive relationship between innovation orientation and process management.

H10: Innovation orientation has a mediation variable effect on the relationship between open leadership and process management.

\section{Methodology}

Within the scope of the study, a survey was conducted with 418 engineers working in production companies. In the analysis, IBM SPSS 25 program, LISREL program and SOBEL calculation tool were used progressively, the data were evaluated and presented in demographic information. Factor analysis and reliability analysis were performed on questions using Likert scale. Correlation analysis was used to examine the relationships between variables, regression analysis was used to test of hypotheses. In the first part of the two-part questionnaire questions, questions about the participants' demographic information and work are included, The second part of the survey consists of scales related to Open Leadership, Innovation Orientation, Employee creativity, Organizational culture and Process Management.

The survey questions consists of questions represent 5 variables. In the first part of the questionnaire, the demographic information of the individuals and the information related to the work are given. In the second part of the questionnaire, there are questions representing 5 variables. In the literature studies for the Open Leadership scale, important studies referenced in many studies have been considered; it was included in the analysis after conducting factor and reliability analysis using the 5-point Likert scale used in the study conducted by Polat and Arabac1 in 2014/2015. The scale developed by Pelham and Wilson (1996) and Hurley and Hult (1998) was used to measure the Innovation Orientation in the sample population. For Employee creativity, Tierney et al. (1999), Tierney and Farmer (2002), Muñoz-Doyague et al. (2008), Gong et al. (2009), Richter et al. (2012), Tierney and Farmer (2011) scales were searched. In measuring organizational culture, the scales used and developed by Wallach (1983), Dension and Neale (1996), Sarros et al. (2005), Cameron and Quinn (2011), Jung et al. (2009) were used. In our scale that Process Management is evaluated, scales used and developed by Choo et al in 2007, Peng et al in 2008, and in Yang et al. in 2016 were used.

\subsection{Research aim}

In this study, it is aimed to determine the effects of open Leadership's Innovation Orientation intervening variable Effect on Employee creativity, Organisational culture and Process Management on engineers working in production sector. The selection of the production sector is due to the fact that product innovation activities take place within this sector. The reason why white-collar engineers are selected is because of their role in both product innovation and creativity and process management. Therefore, the aim of our research is to evaluate and analyze production firms in terms of both leadership and innovation and organizational culture, creativity and process management. To test the propositions, a field survey was conducted using the survey.

\subsection{Findings}

Our questionnaire was applied on 126 firms. 418 engineers working in these companies participated in the survey. 348 of the participants were male and 70 of them were female. $36.7 \%$ of the participants were between the ages of 17-27 and $49.7 \%$ of them were between the ages of $28-40$. The number of participants over the age of 41 is $13.1 \% .83 .9 \%$ of the employees who answered the questionnaire were university graduates, $15 \%$ of them have master's degree and $1.1 \%$ have $\mathrm{PhD}$ degree. The level of achievement of the goals of the employees stated by 36 participants as "Too Low", 58 of them as "Low", 147 of them "Medium" 132 of them "High" 45 of them "Very High".

\subsection{Research framework}

Based on literature search, a research model as Independent Variables; Open Leadership, Intervening 


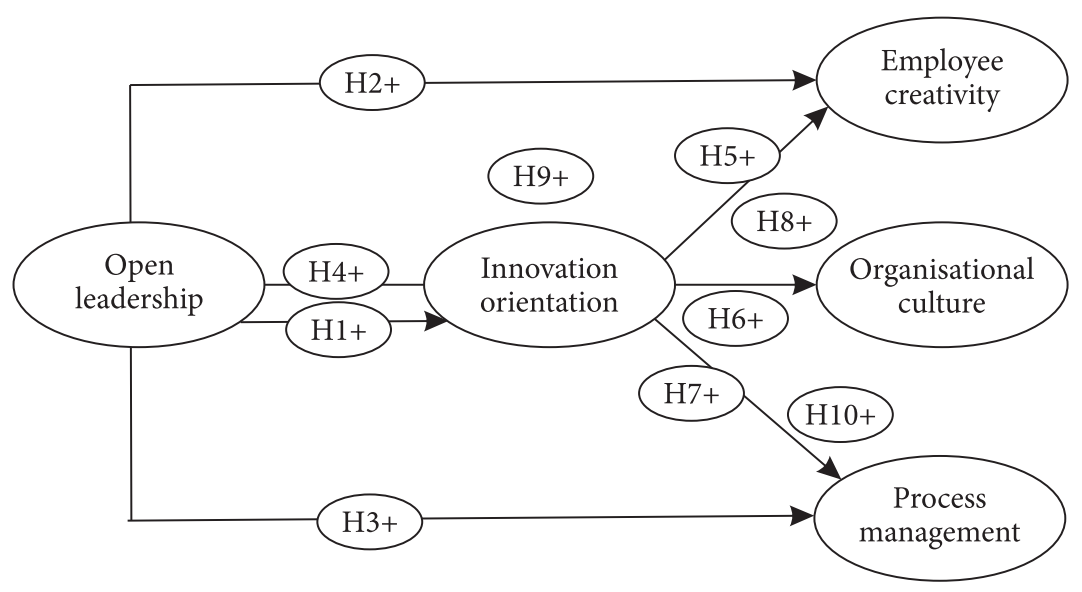

Figure 1. Research model

Variable; Innovation Orientation, Dependent Variables; Employee Creativity, Organizational Culture and Process Management was applied. In the study, a quantitative approach was adopted because the data were analyzed in order to determine the relationship between the statistical concepts. In a quantitative research test, we use the independent or dependent variable to judge the effect on the dependent variable (Thomas et al. 2015). The research model is presented in Figure 1.

\section{Analysis}

Factor analysis was performed to investigate the construct validity of the scale used in the study. Büyüköztürk (2014) defines factor analysis as a multivariate statistical method which aims to explore a few unrelated conceptually significant new variables (factors, dimensions) by combining the variables related to each other. In order to determine whether the data obtained from pretreatment were suitable for factor analysis, the Kaiser-Meyer Olkin (KMO) sample suitability test and Bartlett's sphericity test were performed to evaluate the diagonal values of the anti-image correlation matrix. In this study, it is examined whether the model given by using confirmatory modeling strategy is supported. For this purpose, a preliminary test of 103 units was performed. In this scale, it is determined how much the structure and the number of the questions will be. Questions that are likely to be misunderstood have still been introduced. The questionnaire presented in the pre-test phase has 43 variables. 11 pre-test results have been excluded from the scale, which do not produce the appropriate factor loads, are misunderstood or most likely misunderstood, with a total of 32 expressions obtained, a structure supported by 5 -factor literature has been reached. The scale was applied to 424 personnel working in different enterprises for the model and model scales supported by the literature. As a result of the study, it was seen that some of the surveys were misunderstood and lowered the scale reliability value and 6 surveys were excluded from the study. For the 418 questionnaires, the hypothesis in the research model will be tested. Factors under each factor, the factor loads obtained by the factor analysis of SPSS, Factor Numbers and the standardized values calculated by the LISREL program and the T values calculated by LISREL are presented in Table 1 .

Table 1 contains the number 1 expressions Open Leadership (OL), number 2 expressions Organization Culture (OC), number 3 expressions Employee Creativity (EC), statement 4 Innovation Orientation (IO) and number 5 expressions Process Management (PM). Factor load values, standardized LISREL results, $t$-test results of the observed variables and $p$-value values showing whether this test result is significant that are created for five different factor by statements are presented in Table 1. According to these results, the analysis results of all observed values are significant (all p-value values $<0.01$ ). KMO and Bartlett's Test results are shown in Table 2 for factor analysis in SPSS 25 program. When Table 2 was examined, the KMO value indicating the suitability of the data for Factor analysis was found to be .953 . KMO is higher than 90 is interpreted as "perfect" result (Tavşancil 2002). While this value shows that the data is appropriate for the analysis, the sig value at the Bartlett's Test is 000 ( $\mathrm{sig}<0.05$ ), which indicates that the data obtained for the factor analysis is Chi-Square is significant and the data comes from a multivariate normal distribution. When the Total Variance Explain table was analyzed in factor analysis, it was seen that a 5 factor structure explained $68 \%$ of the structure to be investigated.

The fit indices obtained from the models are given in Table 3. If the values in the table are examined, it can be seen that the model has good fit values for all goodness of fit values (Erkorkmaz et al. 2013, Jöreskog and Sörbom 1993, Kline 2015, MacCallum et al. 1996, Schermelleh-Engel et al. 2003, Tabachnick and Fidell 2007, Wheaton et al. 1977).

In the next part of the analysis, the relationship between the reliability analysis and the questions was revealed. In the literature, Nunnally (1978)'s Cronbach Alpha coefficient 
Table 1. SPSS factor results and lisrel results

\begin{tabular}{|c|c|c|c|c|c|}
\hline Items & F.N. & $\begin{array}{c}\text { F. } \\
\text { Scores }\end{array}$ & $\begin{array}{c}\text { S. } \\
\text { Scores }\end{array}$ & $\begin{array}{c}\mathrm{T} \\
\text { Scores }\end{array}$ & $\mathrm{p}$-value \\
\hline $\begin{array}{l}\text { Twitter, facebook and other social networks are used by managers when it is } \\
\text { necessary for in house communication. }\end{array}$ & 1 & .938 & .71 & 20.78 & .000 \\
\hline Employees are encouraged to develop leadership skills. & 1 & .916 & .69 & 21.65 & .000 \\
\hline $\begin{array}{l}\text { Social networks such as twitter, facebook, etc. are used in order to be informed } \\
\text { of internal information updates. }\end{array}$ & 1 & .832 & .74 & 22.14 & .000 \\
\hline $\begin{array}{l}\text { The use of social technologies such as twitter, facebook, etc. within the } \\
\text { institution is encouraged. }\end{array}$ & 1 & .806 & .88 & 26.91 & .000 \\
\hline $\begin{array}{l}\text { Announcements on any subject are made using social networking technologies } \\
\text { such as twitter, facebook, etc. }\end{array}$ & 1 & .797 & .79 & 23.74 & .000 \\
\hline Social networks are used to facilitate communication in the institution. & 1 & .770 & .88 & 24.59 & .000 \\
\hline $\begin{array}{l}\text { Sufficient time is spent for the disclosure of managerial decisions to the } \\
\text { employees of the institution. }\end{array}$ & 1 & 690 & .84 & 22.25 & .000 \\
\hline Employees who exhibit potential leadership behaviors are favorably supported. & 1 & 670 & .83 & 24.18 & .000 \\
\hline Employees feel comfortable sharing information. & 1 & .604 & .86 & 23.23 & .000 \\
\hline $\begin{array}{l}\text { My organization monitors strictly established systems and operational } \\
\text { procedures. }\end{array}$ & 2 & .884 & .58 & 22.67 & .000 \\
\hline Employees trust each other. & 2 & .866 & .58 & 21.67 & .000 \\
\hline Organizational hierarchy is quite strict. & 2 & .791 & .59 & 21.22 & .000 \\
\hline It always encourages employees for creativity. & 2 & .766 & .57 & 19.17 & .000 \\
\hline The failure of the institution is seen as an opportunity for development. & 2 & .756 & .62 & 23.32 & .000 \\
\hline The interaction between members in my institution is very important. & 2 & .756 & .62 & 23.03 & .000 \\
\hline The institution I work for is seen as an opportunity for learning failure. & 2 & .724 & .61 & 23.85 & .000 \\
\hline The institution I work with encourages trial and error. & 2 & .627 & .59 & 24.06 & .000 \\
\hline Employees in the institution I work in likes challenging tasks. & 2 & .575 & .46 & 14.43 & .000 \\
\hline $\begin{array}{l}\text { I am looking for ways to solve new ideas and problems in the institution where } \\
\text { I work. }\end{array}$ & 3 & .888 & 61 & 20.60 & .000 \\
\hline In my institution, I produce new but executable business-related ideas. & 3 & .804 & .67 & 27.05 & .000 \\
\hline I am looking for new ways of doing business in my institution. & 3 & .787 & .56 & 21.57 & .000 \\
\hline I give importance to authenticity in my work. & 3 & 685 & .62 & 22.23 & .000 \\
\hline $\begin{array}{l}\text { Innovation at my institution is easily accepted for program / project } \\
\text { management. }\end{array}$ & 4 & .850 & .54 & 14.07 & .000 \\
\hline The organization I work for actively seeks innovative ideas. & 4 & .580 & .55 & 20.00 & .000 \\
\hline Employees at my institution are free to express their innovative ideas. & 4 & .572 & .67 & 21.09 & .000 \\
\hline The institution I work in emphasizes the need for innovation for development. & 4 & .502 & .64 & 17.13 & .000 \\
\hline $\begin{array}{l}\text { Innovations based on research results are readily accepted in the institution I } \\
\text { work with. }\end{array}$ & 4 & .484 & 60 & 20.62 & .000 \\
\hline Faulty products may find operational errors before they reach customers. & 5 & .828 & .82 & 24.05 & .000 \\
\hline In my institution, most of all transactions are under quality control. & 5 & 690 & .61 & 15.89 & .000 \\
\hline The institution I work with always meets different customer needs. & 5 & .633 & .72 & 22.22 & .000 \\
\hline $\begin{array}{l}\text { The institution has the experience and knowledge required for today's problem } \\
\text { solving. }\end{array}$ & 5 & .540 & .72 & 22.72 & .000 \\
\hline $\begin{array}{l}\text { It has the ability to perform smoothly in an integrated manner on all } \\
\text { production lines. }\end{array}$ & 5 & .537 & .67 & 20.05 & .000 \\
\hline
\end{tabular}


Table 2. KMO and Bartlett's test results

\begin{tabular}{|l|l|c|}
\hline \multicolumn{2}{|l|}{$\begin{array}{l}\text { Kaiser-Meyer-Olkin Measure of Sampling } \\
\text { Adequacy. }\end{array}$} & .953 \\
\hline $\begin{array}{l}\text { Bartlett's Test of } \\
\text { Sphericity }\end{array}$ & Approx. Chi-Square & 13967.194 \\
\cline { 2 - 3 } & df & 496 \\
\hline & Sig. & .000 \\
\hline
\end{tabular}

Table 3. Goodness fit index value and reference ranges

\begin{tabular}{|l|c|l|}
\hline \multicolumn{1}{|c|}{$\begin{array}{c}\text { Goodness of Fit } \\
\text { Statistics }\end{array}$} & Value & \multicolumn{1}{c|}{ Reference Values } \\
\hline Chi-Square () & 2258.16 & $2<() / \mathrm{Df}<5$ good fit \\
\hline Degrees of Freedom & 454 & $\begin{array}{l}\text { RMSEA }<0.05 \text { perfect fit } \\
\text { RMSEA }<0.08 \text { good fit } \\
0,08=<\text { RMSEA }<0.10 \\
\text { mediocre fit } \\
0.10=>\text { RMSEA poor fit }\end{array}$ \\
\hline $\begin{array}{l}\text { Rquare Error of } \\
\text { Approximation } \\
\text { (RMSEA) }\end{array}$ & 0.079 & RMR $<0.05$ \\
\hline $\begin{array}{l}\text { Root Mean Square } \\
\text { Residual (RMR) }\end{array}$ & 0.042 \\
\hline $\begin{array}{l}\text { Normed Fit Index } \\
\text { (NFI) }\end{array}$ & 0.96 & NFI $>0.95$ good fit \\
\hline $\begin{array}{l}\text { Non-Normed Fit } \\
\text { Index }\end{array}$ & 0.97 & NNFI $>0.95$ good fit \\
\hline $\begin{array}{l}\text { Comparative Fit } \\
\text { Index (CFI) }\end{array}$ & 0.97 & CFI $>0.95$ good fit \\
\hline $\begin{array}{l}\text { Relative Fit İndex } \\
\text { (RFI) }\end{array}$ & 0.96 & $\begin{array}{l}0<\text { RFI }<1 \text { l'e Close to 1 } \\
\text { better fit }\end{array}$ \\
\hline $\begin{array}{l}\text { Goodness of Fit } \\
\text { Index (GFI) }\end{array}$ & \begin{tabular}{l} 
GFI $>0.85$ \\
\hline
\end{tabular} & 0.87 \\
\hline
\end{tabular}

Table 4. Reliability statistics

\begin{tabular}{|l|c|c|}
\hline \multicolumn{1}{|c|}{ Factors } & $\begin{array}{c}\text { Number of } \\
\text { Items }\end{array}$ & $\begin{array}{c}\text { Cronbach Alfa } \\
(\alpha) \text { Values }\end{array}$ \\
\hline Open Leadership (OL) & 9 & .940 \\
\hline Organization Culture (OC) & 9 & .917 \\
\hline Employee Creativity (EC) & 4 & .867 \\
\hline Innovation Orientation (IO) & 5 & .812 \\
\hline Process Management (PM) & 5 & .858 \\
\hline
\end{tabular}

of 0.50 and above measurements are considered to be sufficient (Nunnally 1978, Büyüköztürk 2014). The reliability coefficients obtained for each factor are given in Table 4.

The correlation coefficient gives the degree of the relationship between the data (Landau 2004). The relationship between the factors themselves is calculated in Table 5. Once the suitability of the data is determined, the testing of the hypotheses will proceed. The results of the hypotheses tested $\mathrm{H} 1-\mathrm{H} 7$ hypotheses below are presented in Table 5.

According to Table 5, the values with double stars next to them have a significant correlation with $1 \%$ significance level. Thus, there is a significant correlation between all factors. R Square values showing how much the argument changes the dependent variable and Sig values calculated for $F$ Value values indicating whether the model is meaningful as a whole are given in Table 5. According to the results, all hypotheses were accepted since all sig values were less than 0.01 . There is a relationship between the given variables. These relationships have also been shown to be correlated with the correlation coefficients.

To test the H8-H10 hypothesis, Sobel test was used to measure the inter-variable effect by multiple regression analysis. The obtained values are given in Table 6 .

When examined, it can be seen that all sig values are smaller than 0.01 . This value indicates that multiple regression equations are significant and can be used for prediction purposes. Intervening variable effects were calculated by Sobel test. Sobel Calculator was used for this test. Firstly, the regression coefficient values between the independent variable and the intermediate variable were determined, and multiple regression was performed for the effect value of the independent and intervening variables on the dependent variable. Thus, a, b, Sa and Sb values to be used in the calculation of Sobel Test were found.

Sobel test equation

$$
\mathrm{z} \text {-value }=\mathrm{a} \times \mathrm{b} / \mathrm{SQRT}(\mathrm{b} 2 \times \mathrm{sa} 2+\mathrm{a} 2 \times \mathrm{sb} 2) .
$$

Calculations have shown that the H8-H9 and H10 hypotheses were accepted. In other words, the Innovation Orientation variable has an intervening variable effect for all hypotheses.

Table 5. The results of the hypotheses tested $\mathrm{H} 1-\mathrm{H} 7$

\begin{tabular}{|l|l|l|c|c|c|c|c|c|}
\hline H & \multicolumn{1}{|c|}{ Independent Variables } & Dependent Variables & Corr. & Std. $\beta$ & Sig. & $\begin{array}{c}\text { Adj. R } \\
\text { Square }\end{array}$ & F Value & $\begin{array}{c}\text { Reject/ } \\
\text { Accept }\end{array}$ \\
\hline H1 & Open Leadership & Innovation Orientation & $.551^{\star *}$ & .551 & .000 & .303 & 268.625 & Accept \\
\hline H2 & Open Leadership & Employee Creativity & $.471^{\star *}$ & .471 & .000 & .220 & 175.440 & Accept \\
\hline H3 & Open Leadership & Process Management & $.709^{\star *}$ & .709 & .000 & .502 & 623.748 & Accept \\
\hline H4 & Open Leadership & Organisational Culture & $.569^{\star *}$ & .569 & .000 & .323 & 295.469 & Accept \\
\hline H5 & Innovation Orientation & Employee Creativity & $.606^{\star *}$ & .606 & .000 & .367 & 358.058 & Accept \\
\hline H6 & Innovation Orientation & Organisational Culture & $.656^{\star *}$ & .656 & .000 & .429 & 464.264 & Accept \\
\hline H7 & Innovation Orientation & Process Management & $.495^{\star *}$ & .495 & .000 & .244 & 199.901 & Accept \\
\hline
\end{tabular}

\footnotetext{
${ }^{* *}$ Correlation is significant at the 0.01 level (2-tailed).
} 
Table 6. Results of multiple regression and mediation effect analysis

\begin{tabular}{|c|c|c|c|c|c|c|c|c|c|}
\hline $\mathrm{H}$ & $\begin{array}{l}\text { Indepen. } \\
\text { Variables }\end{array}$ & $\begin{array}{c}\text { Depen. } \\
\text { Variables }\end{array}$ & Std. $\beta$ & Sig. & $\begin{array}{c}\text { Adj. } \\
\text { R Square }\end{array}$ & F Value & $\begin{array}{c}\text { Sobel } \\
\text { Test Stat. }\end{array}$ & $\begin{array}{c}\text { Sobel } \\
\text { P-Value }\end{array}$ & $\begin{array}{l}\text { Reject, } \\
\text { Accep }\end{array}$ \\
\hline \multirow{2}{*}{ H8 } & \begin{tabular}{|l|} 
Open \\
Leadership \\
\end{tabular} & \multirow{2}{*}{$\begin{array}{l}\text { Employee } \\
\text { Creativity }\end{array}$} & .498 & .000 & \multirow{2}{*}{.392} & \multirow{2}{*}{200.293} & \multirow{2}{*}{$10.23^{* * *}$} & \multirow{2}{*}{.000} & \multirow{2}{*}{ Accept } \\
\hline & \begin{tabular}{|l|} 
Innovation \\
Orientation \\
\end{tabular} & & .196 & .000 & & & & & \\
\hline \multirow{2}{*}{ H9 } & \begin{tabular}{|l|} 
Open \\
Leadership \\
\end{tabular} & \multirow{2}{*}{$\begin{array}{l}\text { Org. } \\
\text { Culture }\end{array}$} & .491 & .000 & \multirow{2}{*}{.490} & \multirow{2}{*}{297.770} & \multirow{2}{*}{$10.82^{* * *}$} & \multirow{2}{*}{.000} & \multirow{2}{*}{ Accept } \\
\hline & \begin{tabular}{|l|} 
Innovation \\
Orientation \\
\end{tabular} & & .299 & .000 & & & & & \\
\hline \multirow{2}{*}{ H10 } & \begin{tabular}{|l|} 
Open \\
Leadership \\
\end{tabular} & \multirow{2}{*}{$\begin{array}{l}\text { Process } \\
\text { Mana- } \\
\text { gement }\end{array}$} & .150 & .000 & \multirow{2}{*}{.517} & \multirow{2}{*}{331.383} & \multirow{2}{*}{$4.34^{* * *}$} & \multirow{2}{*}{.000} & \multirow{2}{*}{ Accept } \\
\hline & $\begin{array}{l}\text { Innovation } \\
\text { Orientation }\end{array}$ & & .627 & .000 & & & & & \\
\hline
\end{tabular}

\section{Discussion}

Human capital plays a major role in achieving success in today's rapidly changing business environment. Considering the development of management science, the importance given to human beings is clearly seen (Palmer and Winters 1993). In order to be successful and achieve a competitive advantage, organizations have attempted to pioneer innovations by effectively using their most valuable assets, human resources. The way to renew the organizations is through the creativity capacity of employees (Budak 1998). Organizational management plays an important role in the discovery or exploration of creativity activities. This important support can be seen in open leadership. Innovative activities can be carried out successfully thanks to open leadership and employees can reflect their ideas and creativity to creativity (Reiter-Palmon and Illies 2004). Creativity is a key element for employees to develop ideas and methods and helps in the development of the organization. In today's business world where competition is accelerated, resource scarcity is significant, and workforce and equipment costs are continuously increasing, every creative action that creates more efficient and efficient business methods plays a very effective role in maintaining the existence and success of the organization (Simsek et al. 1998). Drucker defined creativity as a creative worker of the 21 st century, who stated that creativity is related to the individual's internal structure and values, but that social, cultural and environmental conditions support or prevent creativity (Drucker 2000). Woodman et al. (1993) described creativity on the individual level as a functioning of personality, talents, cognitive style, knowledge, intrinsic motivation, social and environmental impacts. Naturally, it is concluded that the results obtained from the research have positive results when it comes to the leadership style of the employees in the organizational culture. A supportive culture consists of trust, interactions, cooperation, incentives and equality among members of the organization; this results in a more friendly organization (Yiing and Ahmad 2009). Chen et al. (2012) also indicate that a supportive culture will provide a harmonious environment in which members can work with other colleagues. This emphasizes the importance of organizational culture. Together with the speed of change in technology, the increasing competition every day forces organizations to develop new products in a dynamic structure and this reveals the importance of long-term impact on performance. One of the pioneering leadership styles to discover this speed of change is open leaders. In open leadership approach, environmental impacts are taken into consideration and paths are determined. Therefore, organizations perform better with an innovative approach. The success of many organizations is achieved by focusing on activities to deliver innovative products to the market. In order to survive in an intense competitive environment, organizations must be innovative in achieving and maintaining competitive power (Calantone et al. 2002). When the literature researches, the concept of innovation; a new perspective, development and presentation of a new product in production, is expressed as the acquisition of a new perspective (Gupta et al. 2007, Anderson et al. 2014). As a result of the analysis of the data collected from various companies in the production sector, it was seen that innovation-oriented companies were successful in their creativity activities and performances. In this success, we can explain the effect of the open leader who manages the production companies with an open system understanding. Because they analyze the developments taking place around the organization and reflect these analyzes to their organizations in a useful way. With the innovation focus, organizations develop products that can be successful in the market and that can meet customer demands and needs and increase the profits of enterprises (Rahman et al. 2016). Innovative organizations improve the management and production 
processes, leading to lower costs and increased productivity (Vazquez et al. 2001). The impact of innovation orientation on new product success performance is also reflected in the developments in financial performance measures such as the return on investments, increase in market share, increase in sales, and increase in profits. It is stated that continuous improvement efforts are in the activities aiming to gradually increase the operational performance (Anand et al. 2009). Research results show that, Leadership style and innovation orientation, organizations must have the name to be successful properties. This success is positively reflected on both employee creativity and organizational culture and process management.

\section{Conclusions}

As a result of the analysis of the surveys obtained from the firms in the manufacturing sector, one of the important leadership styles that the organization must have in order to be successful in the creative activities and process management of organizations is the open leadership role. Open leaders are leaders who can make all kinds of comments about the activities carried out. However, employees should also be aware that they will be responsible for the consequences of abuse of this right to comment. Therefore, in order to put forward successful products as a result of the innovation activities and to prevent the competitors in a competitive environment, employees must use the opportunity given to them by the open leadership in order to be able to implement their ideas and ideas freely. Open leaders are the style of leadership that provides the development of a sense of trust within the organization, and recognizes the importance of supporting this with continuous sharing, and gives an accountability philosophy. It should maintain a leadership path with the virtue of forgiving failures as necessary by supporting all kinds of curiosity and modesty (Polat and Arabac1 2014). Employees participate in an organizational culture that can share their thoughts with confidence thanks to this leadership style. Innovation orientation has been providing innovative behavior to improve quality and significant benefits over many years. Particularly in the research, the result of the innovation orientation variable was found to be both organizational culture and creativity and process management. It is an inevitable fact that the organizations in the production sector have innovation orientation. Looking at the practices of successful companies, doing what they do does not always give the right results. Even if a company achieves consistently successful results for ten or fifteen years, it is not a guarantee that it will survive next year. Management professors Hamel and Prahalad (2017) reminds us that companies must rethink how they will succeed in the face of ruthless competition and dizzying change. Today, there is a lot of evidence that the old-fashioned management model is no longer working: Over the last 20 years, most companies have undergone numerous restructuring. Few of them succeeded. Hamel (2012) says that these interim measures no longer work, that companies need Management Renaissance rather than reorganization. Innovation and freedom ideology lies at the heart of the management renaissance. It is the leadership style that nurtures the ideology of freedom. The results of the research show that the importance of leadership and innovation emerges. If it is thought that it is away from innovation, this will blunt the organization's ability to compete. This situation has been seen in technology-oriented organizations in the past years. For example, the reason why Nokia and Sony companies fell back against their rivals is because they understand the concept of innovation late and they move away from the competition as a result of this delay. We can define creativity from the definitions of creativity in the literature as producing new, original, useful and helpful ideas and methods in any subject. Redmond et al. (1993) stated that the individual is the most important source of creativity. The performances of the organizations where creativity activities are intense are constantly developing in a positive way. The basis of creative activities is the management's support to create new and original ideas for employees (DiLiello and Houghton 2006). With the support of management, the creative activities of the employees are progressing positively (West 2002). The results of the research support the literature, both open leadership and innovation orientation can be explained that positively affect the creativity activities of employees. If organizations want to support employees' creativity activities, they should be focused on innovation (Gupta and Banerjee 2016). On the basis of continuous product innovation, creativity lies. Members of the organization involved in an innovative culture are more creative and free; therefore, they are more likely to be entrepreneurs (Chen et al. 2012). In addition, this insight provides insights into the need to overcome challenging tasks such as understanding customer needs, analyzing product problems, developing new product processes and learning new skills while participating in process management activities. With regard to the effective implementation of these challenging tasks, the literature on employee performance suggests that the creativity of employees can be highly relevant, with the creative workers seeking innovation and excellence in their tasks and tend to perform dynamically well (Baer and Oldham 2006).

\section{References}

Adeel A, Batool S, Ali R (2018) Empowering leadership and team creativity: understanding the direct-indirect path. Business: Theory and Practice 19: 242-254.

https://doi.org/10.3846/btp.2018.24 
Amabile TM (1983) The social psychology of creativity. New York: Springer-Verlag, 18.

https://doi.org/10.1007/978-1-4612-5533-8

Amabile TM (1995) Attributions of creativity: what are the consequences? Creativity Research Journal 8 (4): 423-426. https://doi.org/10.1207/s15326934crj0804_10

Anand G, Ward PT, Tatikonda MV, Schilling DA (2009) Dynamic capabilities through continuous improvement infrastructure. Journal of Operations Management 27 (6): 444-461. https://doi.org/10.1016/j.jom.2009.02.002

Anderson N, Potočnik K, Zhou J (2014) Innovation and creativity in organizations: A state-of-the-science review, prospective commentary, and guiding framework. Journal of Management 40 (5): 1297-1333. https://doi.org/10.1177/0149206314527128

Baer M, Oldham GR (2006) The curvilinear relation between experienced creative time pressure and creativity: moderating effects of openness to experience and support for creativity. Journal of Applied Psychology 91 (4): 963. https://doi.org/10.1037/0021-9010.91.4.963

Barker A (2002) Yenilikçiliğin Simyası, çev. Kardam, A, Mess Yayınları (391).

Boden MA (1990) The creative mind (253 p.). New York: Weidenfeld/Abacus \& Basic Books.

Budak G (1998) Yenilikçi yönetim: yaratıcı birey. İstanbul, 1. Basım. Sistem Yayıncılık.

Büyüköztürk Ş (2014) Sosyal Bilimler İçin Veri Analizi El Kitabı: İstatistik, Araştırma Deseni SPSS Uygulamaları ve Yorum (Genişletilmiş 20. Baskı), Ankara: Pegem Akademi.

Calantone RJ, Cavusgil ST, Zhao Y (2002) Learning orientation, firm innovation capability, and firm performance. Industrial Marketing Management 31 (6): 515-524.

https://doi.org/10.1016/S0019-8501(01)00203-6

Cameron KS, Quinn RE (2011) Diagnosing and changing organizational culture: Based on the competing values framework. John Wiley \& Sons.

Camic C (1986) The matter of habit. American Journal of Sociology 91 (5): 1039-1087. https://doi.org/10.1086/228386

Carbonell P, Rodríguez-Escudero AI, Pujari D (2009) Customer involvement in new service development: An examination of antecedents and outcomes. Journal of Product Innovation Management 26 (5): 536-550.

https://doi.org/10.1111/j.1540-5885.2009.00679.x

Castellion G (2012) Is the $\% 80$ product failure rate statistic actually true http://www.quora.com/ProductManagement/ Is-the-80-product-failure-rate-statisticactually-true

Castellion G, Markham SK (2013) Perspective: new product failure rates: influence of argumentum ad populum and selfinterest. Journal of Product Innovation \& Management and Published JPIM 30: 976-979.

https://doi.org/10.1111/j.1540-5885.2012.01009.x

Černe M, Jaklič M, Škerlavaj M (2013) Authentic leadership, creativity, and innovation: A multilevel perspective. Leadership 9 (1): 63-85. https://doi.org/10.1177/1742715012455130

Charbonnier-Voirin A, El Akremi A, Vandenberghe C (2010) A multilevel model of transformational leadership and adaptive performance and the moderating role of climate for innovation. Group \& Organization Management 35 (6): 699-726. https://doi.org/10.1177/1059601110390833
Chen IC, Ng HF, Li HH (2012) A multilevel model of patient safety culture: cross-level relationship between organizational culture and patient safety behavior in Taiwan's hospitals. The International Journal of Health Planning and Management 27 (1): 65-82. https://doi.org/10.1002/hpm.1095

Chen JS, Tsou HT, Huang AYH (2009) Service delivery innovation: antecedents and impact on firm performance. Journal of Service Research 12 (1): 36-55.

https://doi.org/10.1177/1094670509338619

Choo AS, Linderman KW, Schroeder RG (2007) Method and psychological effects on learning behaviors and knowledge creation in quality improvement projects. Management Science 53 (3): 437-450. https://doi.org/10.1287/mnsc.1060.0635

Colbert BA (2004) The complex resource-based view: Implications for theory and practice in strategic human resource management. Academy of Management Review 29 (3): 341358. https://doi.org/10.5465/amr.2004.13670987

Dension DR, Neale WS (1996) Dension organizational culture survey, Facilitator guide. Ann Arbor, MI: Aviat.

Deshpandé R, Farley JU, Webster Jr FE (1993) Corporate culture, customer orientation, and innovativeness in Japanese firms: a quadrad analysis. Journal of Marketing 57 (1): 23-37. https://doi.org/10.1177/002224299305700102

Dewey BI (2019) Open leadership for a vibrant future. Portal: Libraries and the Academy 19 (3): 359-364. https://doi. org/10.1353/pla.2019.0021

DiLiello TC, Houghton JD (2006) Maximizing organizational leadership capacity for the future: Toward a model of selfleadership, innovation and creativity. Journal of Managerial Psychology 21 (4): 319-337. https://doi.org/10.1108/02683940610663114

Dragoni L (2005) Understanding the emergence of state goal orientation in organizational work groups: the role of leadership and multilevel climate perceptions. Journal of Applied Psychology 90 (6): 1084.

https://doi.org/10.1037/0021-9010.90.6.1084

Drucker FP (2000) Gelecek İçin Yönetim 1990’lar ve Sonrası, Çev. Fikret Üçcan, Türkiye İş Bankası Kültür Yayınları, Minpa Matbaacılık Tic. Ltd. Şti, Ankara, Nisan.

Erkorkmaz Ü, Etikan İ, Demir O, Özdamar K, Sanisoğlu SY (2013) Doğrulayıcı faktör analizi ve uyum indeksleri. Turkiye Klinikleri Journal of Medical Sciences 33 (1): 210-223. https://doi.org/10.5336/medsci.2011-26747

Gatignon H, Xuereb JM (1997) Strategic orientation of the firm and new product performance. Journal of Marketing Research 34 (1): 77-90. https://doi.org/10.1177/002224379703400107

Gong Y, Huang JC, Farh JL (2009) Employee learning orientation, transformational leadership, and employee creativity: The mediating role of employee creative self-efficacy. Academy of Management Journal 52 (4): 765-778. https://doi.org/10.5465/amj.2009.43670890

Gupta R, Banerjee P (2016) Antecedents of organisational creativity: a multi-level approach. Business: Theory and Practice 17: 167. https://doi.org/10.3846/btp.2016.624

Gupta AK, Tesluk PE, Taylor MS (2007) Innovation at and across multiple levels of analysis. Organization Science 18 (6): 885897. https://doi.org/10.1287/orsc.1070.0337

Hamel G (2006) The why, what, and how of management innovation. Harvard Business Review 84 (2): 72. 
Hamel G (2012) What matters now. Strategic Direction 28 (9). https://doi.org/10.1108/sd.2012.05628iaa.012

Hamel G, Prahalad CK (2017) Do you really have a global strategy? In International Business (pp. 285-294). Routledge. https://doi.org/10.4324/9781315199689-18

Han JK, Kim N, Srivastava RK (1998) Market orientation and organizational performance: is innovation a missing link? Journal of Marketing 62 (4): 30-45. https://doi.org/10.1177/002224299806200403

Higgins M, Morgan J (2000) The role of creativity in planning: The "creative practitioner". Planning Practice \& Research 15 (1-2): 117-127. https://doi.org/10.1080/713691881

Hooper D, Coughlan J, Mullen M (2008) Structural equation modelling: Guidelines for determining model fit. Articles, 2.

Hurley RF, Hult T (1998) Innovation, market orientation, and organizational learning: An integration and empirical examination. Journal of Marketing 62 (3): 42-54. https://doi.org/10.1177/002224299806200303

Johan AP, Handika RF (2018) A qualitative investigation on the successful turnaround strategy from top leader perspectives: examples from Indonesia. Business: Theory and Practice 19: 114-122. https://doi.org/10.3846/btp.2018.12

Johnson SP, Menor LJ, Roth AV, Chase RB (2000) A critical evaluation of the new service development process. New service development: Creating memorable experiences, 1-32. https://doi.org/10.4135/9781452205564.n1

Jöreskog KG, Sörbom D (1993) LISREL 8: Structural equation modeling with the SIMPLIS command language. Scientific Software International, 133-158.

Jung CG (1933) Modern man in search of a soul. Translated by WS Dell and CF Baynes. Harcourt, Brace \& World, New York, NY.

Jung DI, Chow C, Wu A (2003) The role of transformational leadership in enhancing organizational innovation: Hypotheses and some preliminary findings. The Leadership Quarterly 14 (4-5): 525-544. https://doi.org/10.1016/S10489843(03)00050-X

Jung T, Scott T, Davies HT, Bower P, Whalley D, McNally R, Mannion R (2009) Instruments for exploring organizational culture: A review of the literature. Public Administration Review 69 (6): 1087-1096. https://doi.org/10.1111/j.1540-6210.2009.02066.x

Karcıoğlu F, Kurt E (2009) Örgütsel iletişimin etkinliği açısından kurumsal bloglar ve birkaç kurumsal blogun incelenmesi. Atatürk Üniversitesi İktisadi ve İdari Bilimler Dergisi 23 (3): 1-17.

Keyes CLM (1998) Social well-being. Social Psychology Quarterly, 121-140. https://doi.org/10.2307/2787065

Kindström D, Kowalkowski C (2009) Development of industrial service offerings: a process framework. Journal of Service Management 20 (2): 156-172.

https://doi.org/10.1108/09564230910952753

Kline RB (2015) Principles and practice of structural equation modeling. Guilford publications.

Koberg CS, Chusmir LH (1987) Organizational culture relationships with creativity and other job-related variables. Journal of Business Research 15 (5): 397-409. https://doi.org/10.1016/0148-2963(87)90009-9
Kotter JP (2011) On what leaders really do (on leadership). Harvard Business Review Press, 37-55.

Lai MF, Lee GG (2007) Risk-avoiding cultures toward achievement of knowledge sharing. Business Process Management Journal 13 (4): 522-537. https://doi.org/10.1108/14637150710763559

Landau S (2004) A handbook of statistical analyses using SPSS. CRC. https://doi.org/10.1201/9780203009765

Lee JC, Shiue YC, Chen CY (2016) Examining the impacts of organizational culture and top management support of knowledge sharing on the success of software process improvement. Computers in Human Behavior 54: 462-474. https://doi.org/10.1016/j.chb.2015.08.030

Levitt T (2002) Creativity is not enough. Harvard Business Review, 80: 138 .

Li C (2010) Open leadership: How social technology can transform the way you lead (1st ed.) Press by A Wiley Imprint, USA: San Francisco.

Lisboa A, Skarmeas D, Lages C (2011) Entrepreneurial orientation, exploitative and explorative capabilities, and performance outcomes in export markets: A resource-based approach. Industrial Marketing Management 40 (8): 1274-1284. https://doi.org/10.1016/j.indmarman.2011.10.013

Lohrke FT, Bedeian AG, Palmer TB (2004) The role of top management teams in formulating and implementing turnaround strategies: a review and research agenda. International Journal of Management Reviews 5 (2): 63-90. https://doi. org/10.1111/j.1460-8545.2004.00097.x

Lok P, Crawford J (2004) The effect of organisational culture and leadership style on job satisfaction and organisational commitment: A cross-national comparison. Journal of Management Development 23 (4): 321-338. https://doi.org/10.1108/02621710410529785

Lopez-Cabrales A, Pérez-Luño A, Cabrera RV (2009) Knowledge as a mediator between HRM practices and innovative activity. Human Resource Management: Published in Cooperation with the School of Business Administration, The University of Michigan and in alliance with the Society of Human Resources Management 48 (4): 485-503. https://doi.org/10.1002/hrm.20295

Lundkvist A, Yakhlef A (2004) Customer involvement in new service development: a conversational approach. Managing Service Quality: An International Journal 14 (2/3): 249-257. https://doi.org/10.1108/09604520410528662

MacCallum RC, Browne MW, Sugawara HM (1996) Power analysis and determination of sample size for covariance structure modeling. Psychological Methods 1 (2): 130. https://doi.org/10.1037/1082-989X.1.2.130

McDermott R, O'dell C (2001) Overcoming cultural barriers to sharing knowledge. Journal of Knowledge Management 5 (1): 76-85. https://doi.org/10.1108/13673270110384428

Melton HL, Hartline MD (2010) Customer and frontline employee influence on new service development performance. Journal of Service Research 13 (4): 411-425. https://doi.org/10.1177/1094670510369378

Mumford MD, Scott GM, Gaddis B, Strange JM (2002) Leading creative people: Orchestrating expertise and relationships. The Leadership Quarterly 13 (6): 705-750. https://doi.org/10.1016/S1048-9843(02)00158-3 
Muñoz-Doyague MF, González-Álvarez N, Nieto M (2008) An examination of individual factors and employees' creativity: The case of Spain. Creativity Research Journal 20 (1): 21-33. https://doi.org/10.1080/10400410701841716

Nijssen EJ, Hillebrand B, Vermeulen PA, Kemp RG (2006) Exploring product and service innovation similarities and differences. International Journal of Research in Marketing 23 (3): 241-251. https://doi.org/10.1016/j.ijresmar.2006.02.001

Nunnally J (1978) Psychometric theory. New York: McGraw-Hill.

Olavarrieta S, Friedmann R (2008) Market orientation, knowledge-related resources and firm performance. Journal of Business Research 61 (6): 623-630.

https://doi.org/10.1016/j.jbusres.2007.06.037

Olson EM, Slater SF, Hult GTM (2005) The performance implications of fit among business strategy, marketing organization structure, and strategic behavior. Journal of Marketing 69 (3): 49-65. https://doi.org/10.1509/jmkg.69.3.49.66362

Ordanini A, Parasuraman A (2011) Service innovation viewed through a service-dominant logic lens: a conceptual framework and empirical analysis. Journal of Service Research 14 (1): 3-23. https://doi.org/10.1177/1094670510385332

Palmer M, Winters TK (1993) İnsan Kaynakları, (çev. Doğan Şahiner), Rota Yayın Yapım Tanıtım Ltd. Şti., İstanbul.

Pelham AM, Wilson DT (1995) A longitudinal study of the impact of market structure, firm structure, strategy, and market orientation culture on dimensions of small-firm performance. Journal of the Academy of Marketing Science 24 (1): 27-43. https://doi.org/10.1177/009207039602400103

Peng DX, Schroeder RG, Shah R (2008) Linking routines to operations capabilities: A new perspective. Journal of Operations Management 26 (6): 730-748.

https://doi.org/10.1016/j.jom.2007.11.001

Perreault WD, Cannon JP, McCarthy EJ (2013) Pazarlamanın Temelleri, Nobel Yayınları. McGraw-Hill\&Irwin.

Polat M, Arabacı İB (2014) Eğitimde açık liderlik ve sosyal ağlar. Journal of World of Turks/Zeitschrift für die Welt der Türken 6 (1): 257-275.

Polat M, Arabaci İB (2015) A brief history of leadership and open leadership. Route Educational and Social Science Journal 2 (1): 207-232. https://doi.org/10.17121/ressjournal.229

Rahman SA, Taghizadeh SK, Ahmad N, Ramayah T (2016) Psychological factors of innovativeness among nomadic micro-entrepreneurs for achieving business growth. Business: Theory and Practice 17: 191. https://doi.org/10.3846/btp.2016.618

Rawlinson JG (1995) Yaratıcı düşünme ve beyin fırtınası [Creative thinking and brainstorming]. İstanbul, Turkey: Rota Yayınları, Bireysel Yatırım Dizisi. Reprosel Matbaa, 21.

Redmond MR, Mumford MD, Teach R (1993) Putting creativity to work: Effects of leader behavior on subordinate creativity. Organizational Behavior and Human Decision Processes 55 (1): 120-151. https://doi.org/10.1006/obhd.1993.1027

Reichstein T, Michelis D (2015) Open leadership (Charlene Li). In Social Media Handbuch (pp. 207-216). Nomos Verlagsgesellschaft mbH \& Co. KG. https://doi.org/10.5771/9783845263823-207

Reiter-Palmon R, Illies JJ (2004) Leadership and creativity: Understanding leadership from a creative problem-solving perspective. The Leadership Quarterly 15 (1): 55-77.

https://doi.org/10.1016/j.leaqua.2003.12.005

Richter AW, Hirst G, Van Knippenberg D, Baer M (2012) Creative self-efficacy and individual creativity in team contexts: Cross-level interactions with team informational resources. Journal of Applied Psychology 97 (6): 1282.

https://doi.org/10.1037/a0029359

Ryff CD, Keyes CLM (1995) The structure of psychological wellbeing revisited. Journal of Personality and Social Psychology 69 (4): 719. https://doi.org/10.1037//0022-3514.69.4.719

Ryff CD, Singer BH (2008) Know thyself and become what you are: A eudaimonic approach to psychological well-being. Journal of Happiness Studies 9 (1): 13-39. https://doi.org/10.1007/s10902-006-9019-0

Sarros JC, Gray J, Densten IL, Cooper B (2005) The organizational culture profile revisited and revised: An Australian perspective. Australian Journal of Management 30 (1): 159-182. https://doi.org/10.1177/031289620503000109

Schein EH (1985) Organizational culture and leadership: a dynamic view. San Francisco, CA.

Schein EM (2004) Organizational culture and leadership (3rd. ed.). Jossy-Bass.

Schermelleh-Engel K, Moosbrugger H, Müller H (2003) Evaluating the fit of structural equation models: Tests of significance and descriptive goodness-of-fit measures. Methods of Psychological Research Online 8 (2): 23-74.

Shin SJ, Kim TY, Lee JY, Bian L (2012) Cognitive team diversity and individual team member creativity: A cross-level interaction. Academy of Management Journal 55 (1): 197-212. https://doi.org/10.5465/amj.2010.0270

Siguaw JA, Simpson PM, Enz CA (2006) Conceptualising innovation orientation: A framework for study and integration of innovation research. Journal of Product Innovation Management 23 (6): 556-574. https://doi.org/10.1111/j.1540-5885.2006.00224.x

Simsek S, Akgemci T, Çelik A (1998) Davranis bilimlerine giris ve orgutlerde davranis. Ankara, Nobel Yayin Dagitim.

Sternberg RJ, Lubart TI (1999) The concept of creativity: Prospects and paradigms. Handbook of Creativity 1: 3-15. https://doi.org/10.1017/CBO9780511807916.003

Szymańska E, Dziedzic E, Rutkowski A (2017) Organisational innovations in health resort-based tourism. Business: Theory and Practice 18: 54. https://doi.org/10.3846/btp.2017.006

Tabachnick BG, Fidell LS (2007) Using multivariate statistics (5th ed.). New York: Allyn and Bacon.

Tavşancıl E (2002) Tutumların ölçülmesi ve SPSS ile veri analizi (1 Basım). Nobel Yayıncılık, Ankara.

Thomas JR, Nelson JK, Silverman SJ (2015) Research methods in physical activity. Human Kinetics, 133-153.

Tierney P, Farmer SM (2002) Creative self-efficacy: Its potential antecedents and relationship to creative performance. Academy of Management Journal 45 (6): 1137-1148. https://doi.org/10.2307/3069429

Tierney P, Farmer SM (2011) Creative self-efficacy development and creative performance over time. Journal of Applied Psychology 96 (2): 277. https://doi.org/10.1037/a0020952

Tierney P, Farmer SM, Graen GB (1999) An examination of leadership and employee creativity: The relevance of traits and 
relationships. Personnel Psychology 52 (3): 591-620. https://doi.org/10.1111/j.1744-6570.1999.tb00173.x

Toffler A (1981) Üçüncü Dalga (Çev. Ali Seden). Altın Kitaplar yayınevi, İstanbul.

Uslu T, Bülbül IA, Çubuk D (2015) An investigation of the effects of open leadership to organizational innovativeness and corporate entrepreneurship. Procedia-Social and Behavioral Sciences 195: 1166-1175.

https://doi.org/10.1016/j.sbspro.2015.06.169

Vazquez R, Santoz ML, Alvarez LI (2001) Market orientation, innovation and competitive strategies in industrial firms. Journal of Strategic Marketing 9: 69-90. https://doi.org/10.1080/09652540123013

Wallach EJ (1983) Individuals and organisations: The cultural match. Training and Development Journal 37 (2): 29-36.

Wang P, Rode JC, Shi K, Luo Z, Chen W (2013) A workgroup climate perspective on the relationships among transformational leadership, workgroup diversity, and employee creativity. Group \& Organization Management 38 (3): 334-360. https://doi.org/10.1177/1059601113488163

Wendra W, Sule ET, Joeliaty J, Azis Y (2019) Exloring dynamic capabilities, intellectual capital and innovation performance relationship: evidence from the garment manufacturing. Business: Theory and Practice 20: 123. https://doi.org/10.3846/btp.2019.12

West MA (2002) Sparkling fountains or stagnant ponds: An integrative model of creativity and innovation implementation in work groups. Applied Psychology 51 (3): 355-387.

https://doi.org/10.1111/1464-0597.00951

Wheaton B, Muthen B, Alwin DF, Summers G (1977) Assessing reliability and stability in panel models. Sociological Methodology 8 (1): 84-136. https://doi.org/10.2307/270754

Williams F, Foti RJ (2011) Formally developing creative leadership as a driver of organizational innovation. Advances in Developing Human Resources 13 (3): 279-296. https://doi.org/10.1177/1523422311424702

Woodman RW, Sawyer JE, Griffin RW (1993) Toward a theory of organizational creativity. Academy of Management Review 18 (2): 293-321. https://doi.org/10.5465/amr.1993.3997517

Yang Y, Lee PK, Cheng TCE (2016) Continuous improvement competence, employee creativity, and new service development performance: A frontline employee perspective. International Journal of Production Economics 171: 275-288. https://doi.org/10.1016/j.ijpe.2015.08.006

Yiing LH, Ahmad KZB (2009) The moderating effects of organizational culture on the relationships between leadership behaviour and organizational commitment and between organizational commitment and job satisfaction and performance. Leadership and Organization Development Journal 30 (1): 53-86. https://doi.org/10.1108/01437730910927106

Zhou KZ, Yim CK, Tse DK (2005) The effects of strategic orientations on technology-and market-based breakthrough innovations. Journal of Marketing 69 (2): 42-60. https://doi.org/10.1509/jmkg.69.2.42.60756 